\title{
THE POTENTIAL OF ENDOPHYTIC Trichoderma FROM OIL PALM (Elaeis guineensis Jacq.) ROOTS OF NORTH SUMATRA, INDONESIA AGAINST Ganoderma boninense
}

\author{
DEDEK HARYADI*; MANJIT S SIDHU**; TUMPAL PANJAITAN**; HADI HENDRA* ${ }^{* *}$ \\ and KHIM PHIN CHONG*
}

\begin{abstract}
Utilisation of endophytic Trichoderma increases tremendously as an alternative control against G. boninense, causal pathogen of basal stem rot (BSR) disease of oil palm. However, investigation of endophytic Trichoderma from Indonesia is still very scarce. The aims of this study were to isolate, identify and investigate the potential of endophytic Trichoderma from oil palm roots. Three potential endophytic Trichoderma species were isolated and further identified using macroscopic, microscopic, and molecular methods. Antagonistic activities of endophytic Trichoderma were tested using dual culture agar and poison food agar assay. A molecular approach using DNA sequencing of 5.8S-ITS region successfully identified the endophytic Trichoderma isolate ET501 as Trichoderma reesei strain RHa, while isolates of endophytic ET523 and ET537 were identified as Trichoderma asperellum isolate F1 and Trichoderma asperellum strain $Q 1$, respectively. Trichoderma reesei $E T 501$ was the most aggressive isolate against $\mathrm{G}$. boninense with PIRG of 95.1\% compared to T. asperellum ET523 and T. asperellum ET537 with PIRG of $87.1 \%$ and $88.9 \%$, respectively. Meanwhile, T. reesei ET501 showed the strongest antibiosis activity with 100\% inhibition in $80 \%$ concentration, compared to T. asperellum ET523 and T. asperellum ET537 which gave $12.3 \%$ and $90.5 \%$ of inhibition, respectively.
\end{abstract}

Keywords: Trichoderma reesei, Trichoderma asperellum, Ganoderma boninense, basal stem rot, endophytic.

Date received: 26 November 2018; Sent for revision: 24 December 2018; Received in final form: 1 Jun 2019; Accepted: 11 October 2019.

\section{INTRODUCTION}

Basal stem rot (BSR) disease caused by a number of Ganoderma species, is the most destructive disease causing significant losses of oil palm yield in Southeast Asia (Turner, 1981). The two largest palm oil producers in the world, Malaysia and Indonesia,

* FGV Chair of Sustainable Oil Palm Management, Faculty of Sustainable Agriculture,

Universiti Malaysia Sabah, UMS Sandakan Campus,

Mile 10, Sg Batang, 90000 Sandakan,

Sabah, Malaysia.

E-mail: chongkp@ums.edu.my

** Asian Agri Research and Development Centre, P.O. Box 35, Bahilang Plantation, Tebing Tinggi, 2600 Deli, North Sumatra, Indonesia. are being threatened by the BSR disease, which is caused by Ganoderma boninense (Cooper et al., 2011; Turner, 1981). About $50 \%$ of the palms are lost with the majority of standing palms showing disease symptoms at the time of replanting after 25 years in North Sumatra (Cooper et al., 2011).

There is no conclusive strategy or method to solve BSR disease effectively to date. However, currently, biological control has been widely implemented in Indonesia oil palm plantation as the main strategy to control and prevention method in integrated disease management (IDM). The demand for alternative control of plant pathogens has become stronger owing to concern about the safety and environmental impacts of chemicals (Schubert 
et al., 2008). Biological control is increasingly being considered as an alternative treatment in sustainable agriculture. Trichoderma spp. are one of the popular biological control agents that are widely used to control BSR disease.

Trichoderma is soilborne and associated with the roots of plants and commonly considered for their potential to control plant diseases with many aspects of endophytic association characteristic (Harman et al., 2004; Vinale et al., 2007). These fungi colonise the root epidermis and outer cortical layers and also release bioactive compounds that cause walling off of the Trichoderma thallus (Harman, 2006). Isolation of Trichoderma from different soils has revealed that several Trichoderma species are highly associated with plant and often as the predominant species in the plant root ecosystem (Kredics et al., 2014).

Identification of Trichoderma strains that have potential as biocontrol agents can be preliminarily conducted using in vitro antagonistic assays (Larralde et al., 2008). This assay is a predictive method to determine the antagonistic activity potential of the biocontrol agents before carrying out time-consuming and more expensive studies (Lo et al., 1998). Identification of fungi species using morphological features is a less precise identification method compared to the molecular approach. Therefore, a molecular approach through polymerase chain reaction (PCR) amplification and sequence analysis are needed to complete a precise identification of Trichoderma.

Due to the importance of endophytic Trichoderma spp. as biocontrol agents against G. boninense in oil palm industry, exploration and investigation about endophytic Trichoderma need to be conducted. Precise identification and characterisation of Trichoderma are also important to optimise the full potential of Trichoderma in many specific needs (Lieckfeldt et al., 1999). The aims of this study were to isolate, identify, and study the potential endophytic Trichoderma from North Sumatra that can be used as a biological control agent against $G$. boninense.

\section{MATERIALS AND METHODS}

\section{Isolation of Endophytic Trichoderma}

The endophytic Trichoderma isolates were isolated from roots of remaining healthy mature oil palm in high disease incidence area in Negeri Lama Estate, Asian Agri Group, North Sumatra, Indonesia in accordance to Elad et al. (1981) with some modifications. Roots sample were surfacesterilised through sequential immersion in $2 \%$ sodium hypochlorite (chlorine bleach), $70 \%$ ethanol and sterilised water followed by blotting dry on a sterile filter paper. Root samples were placed onto Trichoderma selective media (TSM) and incubated for seven days at room temperature $\left(27^{\circ} \mathrm{C} \pm 2\right)$. Each distinct fungal colony was sub-cultured on potato dextrose agar (PDA) and incubated for seven days at room temperature.

Pure cultures of endophytic Trichoderma were used for further study. A total of 20 endophytic Trichoderma isolates were obtained from Negeri Lama Estate and subjected to dual culture assay, a preliminary assay to screen mycoparasites potential through antagonistic activity against G. boninense (data not shown). From the preliminary assay, three most potential endophytic Trichoderma (ET501, ET523, and ET537) were selected for further identification and investigation to evaluate their aggressiveness against $G$. boninense using dual culture agar and antibiosis properties through poison food agar assay.

\section{Identification of Endophytic Trichoderma}

Morphological observation. Morphological observation of endophytic Trichoderma isolates was conducted by observing both macroscopic and microscopic fungal colonies. For macroscopic observation, the morphological feature was observed and the growth rate recorded up to five days from the measurement of five replicates. Meanwhile, for microscopic observation, mycelia from each isolate were taken from PDA plate and spread onto a clean slide mounted with a drop of water and observed under a light microscope using 1000X magnification. After that, the microscopic feature was compared to the monograph prepared by Rifai (1969).

\section{Molecular Identification}

DNA extraction and PCR amplification. Extraction of endophytic Trichoderma DNA was done using the mini protocol for purification of total DNA from fungi tissue with Invitrogen DNA isolation kit with modifications. Approximately, $100 \mathrm{mg}$ of Trichoderma mycelia originally grown in PDA were further extracted following the DNA extraction protocol. PCR amplification of the Trichoderma DNA was done at ITS1 and ITS2 regions and the 5.8S gene using ITS 1 and ITS 4 primers. TAE agarose 1.5\% $(\mathrm{w} / \mathrm{v})$ was used for the agarose gel electrophoresis with $100 \mathrm{~V}$ for 60 min with a size of PCR amplicon approximately $570 \mathrm{bp}$. The reaction was performed in $10 \mu \mathrm{l}$ PCR mixes, 10× PCR buffer $1 \mu \mathrm{l}, 0.1 \mu \mathrm{l}$ $\mathrm{dNTP}, 0.5 \mu \mathrm{l}$ forward and reverse primers, $0.1 \mu \mathrm{l}$ Taq polymerase [New England Biolabs (NEB)], $1 \mu \mathrm{l}$ of DNA template and $6.8 \mu \mathrm{l}$ RNase-free water. The primer sequences used were ITS 1: 5' -TCC GTA GGT GAA CCT GCG G $-3^{\prime}$ as forward primer and ITS 4: 5' - TCC GCT TAT TGA TAT GC - $3^{\prime}$ as reverse primer with the initial denaturation was set at $95^{\circ} \mathrm{C}$ for 5 min, followed by 30 cycles of denaturation at $95^{\circ} \mathrm{C}$ for $1 \mathrm{~min}$, annealing at $59^{\circ} \mathrm{C}$ for $30 \mathrm{~s}$, extension at $72^{\circ} \mathrm{C}$ for $30 \mathrm{~s}$, and final extension at $72^{\circ} \mathrm{C}$ for $5 \mathrm{~min}$. 
DNA sequencing and sequence analysis. DNA sequencing was done at Bioneer Laboratory (South Korea). The sequences obtained were further analysed using Basic Local Alignment Search Tool (BLAST) to obtain the closest matches sequence in the National Centre for Biotechnology Information (NCBI) GenBank database. A phylogenetic tree was constructed using Molecular Evolutionary Genetics Analysing (MEGA) software with Neighbour-Joining method and 1000 bootstraps to show the relationships among the homologous microorganisms.

\section{Dual Culture Assay}

A $6 \mathrm{~mm}$ diameter of $\mathrm{G}$. boninense agar disc from Negeri Lama Estate that has been identified was taken from the edge of actively growing pure culture (five days) and placed on PDA $1 \mathrm{~cm}$ from the edge of the $9 \mathrm{~cm}$ petri dish. The G. boninense was allowed to grow for three days by which time the colony reached to $\pm 2 \mathrm{~cm}$. After that, a $6 \mathrm{~mm}$ diameter disc of endophytic Trichoderma isolate was taken from the pure culture of isolated endophytic Trichoderma, then placed on the opposite side of the petri dish containing G. boninense separately, while control petri dish contained only G. boninense. The assay was incubated for six days. The antagonistic activity of the endophytic Trichoderma isolates was measured using the formula of percentage inhibition of radial growth (PIRG) following Bivi et al. (2010).

$$
\mathrm{PIRG}=\frac{\mathrm{R} 1-\mathrm{R} 2}{\mathrm{R} 1} \times 100 \%
$$

where PIRG = percent inhibition of radial growth of Ganoderma, R1= represent the radial growth of Ganoderma in the absence of endophytic Trichoderma, while $\mathrm{R} 2=$ represent the radial growth of Ganoderma in the presence of endophytic Trichoderma.

\section{Poison Food Agar Assay}

Five-day old endophytic Trichoderma (ET501, ET523 and ET537) conidia were harvested from cultures grown at room temperature on PDA by placing $10 \mathrm{ml}$ of sterile distilled water on the plate surface and slowly agitating using a sterile glass rod. The concentrated endophytic Trichoderma spores suspension was collected and filtered through sterile glass wool for mycelium removal. The concentrated suspension was adjusted to $1 \times 10^{6}$ conidia using haemocytometer. About $200 \mathrm{ml}$ potato dextrose broth (PDB) was prepared into a conical flask and inoculated with $1 \mathrm{ml}$ of endophytic Trichoderma suspension and incubated in orbital shaker incubator with 0.78 RCF for seven days at room temperature. The mycelia were removed by filtration after seven days of growth and the filtrate was sterilised by passing through a $0.22 \mu \mathrm{m}$ membrane disposable unit (Sundram, 2013). The culture filtrate from conidia of endophytic Trichoderma was incorporated into PDA at $20 \%, 40 \%, 60 \%$, and $80 \%$ concentration according to the method as described by Sundram (2013).

$$
\mathrm{PIMG}=\frac{\mathrm{R} 1-\mathrm{R} 2}{\mathrm{R} 1} \times 100 \%
$$

PIMG is percent inhibition of mycelia growth. $\mathrm{R} 1$, radial growth of Ganoderma in the absence of antagonist fungal. R2, radial growth of Ganoderma in the presence of antagonist.

\section{Scanning Electron Microscopy Observation}

Scanning electron microscopy (SEM) observation was conducted in the Integrated Research and Testing Laboratory, Universitas Gadjah Mada, Yogyakarta in Indonesia. Zones of interaction between $G$. boninense and endophytic Trichoderma spp. on PDA medium after six days were prepared for observation using SEM. Each agar plate with fungal mycelia was first excised using a scalpel and trimmed to approximately $10 \mathrm{~mm} \times 10 \mathrm{~mm}$ in size and as thin as possible to reduce the moisture. Samples were dried at $60^{\circ} \mathrm{C}$ for $90 \mathrm{~min}$ maximum. Samples were mounted on platinum formvar, coated with the platinum ion in JEOL JEC-3000FC auto fine coater for $1 \mathrm{~min}$ and vacuum until 2 pa of pressure, this treatment was replicated for two times. Samples were observed under a JEOL JSM 6510 LA SEM.

\section{RESULTS AND DISCUSSION}

\section{Endophytic Trichoderma Isolates}

All colonies of endophytic Trichoderma emerged from TSM after three to seven days of incubation at room temperature (Figure 1). Samuels (2004) reported that incubation temperature is an important taxonomic criterion for Trichoderma identification, but most of the endophytic Trichoderma species grow optimally at $25^{\circ} \mathrm{C}-30^{\circ} \mathrm{C}$. Initial mycelium of endophytic Trichoderma morphological characteristics on PDA appeared as white hyphal growth followed by green conidiation on the fourth to fifth day after plating. The same result was also reported by Sundram (2013), where young Trichoderma morphological characteristics also appeared as faint white hyphal growth followed by green conidiation initiating from the centre of the plate.

\section{Morphological Characteristics}

Colony characteristics of endophytic Trichoderma. The morphological characteristics of endophytic 
Trichoderma species have been used to characterise and distinguish the species of isolates (Gams and Bissett, 1998). Certain colony characters such as growth rate, colony appearance, and pigmentation can be the main characteristics of a species. Preliminary identification was carried out which showed that all isolates were endophytic Trichoderma species. Growth rate results for all endophytic Trichoderma isolates are shown in Table 1. The isolate of endophytic Trichoderma ET501 grew as the fastest isolate which fully colonised the petri dish in four days of incubation time, while endophytic Trichoderma ET523 and ET537 isolates fully colonised the petri dish in five days of incubation.

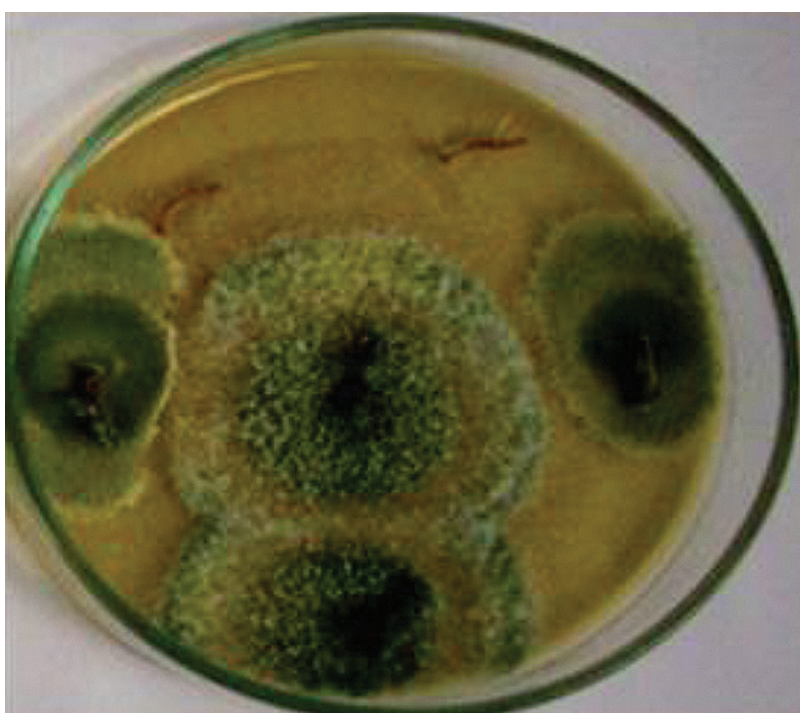

Figure 1. Endophytic Trichoderma isolates from oil palm roots on Trichoderma selection media (TSM).
The conidia were dispersed and formed concentric rings pattern in all isolates within five days of incubation (Figure 2). Samuels (2004) reported that conidia of most of Trichoderma species will form within a week of incubation. Concentric ring of endophytic Trichoderma ET523 isolate was growing densely compared to endophytic Trichoderma ET537 and ET501 isolates. The endophytic Trichoderma ET537 isolate appearance was more cottony than endophytic Trichoderma ET523 and ET501 isolates. The same result was also reported by Shah et al. (2012) where some of Trichoderma species showed white cottony mycelium with green conidiation towards the margins. The colour of mature conidia of endophytic Trichoderma ET501 isolate was yellowish green (Figure 2a), while conidia of endophytic Trichoderma ET523 and ET537 were greyish green colour (Figures $2 b$ and $2 c$, respectively). Sekhar et al. (2017) also reported that Trichoderma spp. conidia vary in colour from dark green to pale yellowish. The endophytic Trichoderma ET501 was found to produce diffusible yellow pigments and caused the PDA to turn yellowish. These diffusible yellow pigments were not found in other isolates. Trichoderma strains within Longibrachiatum species typically have conspicuous bright greenish yellow pigments, at least when first isolated (Samuels, 2004).

Microscopic features of endophytic Trichoderma $s p p$. The microscopic features of endophytic Trichoderma revealed different characteristic between the isolates. The shapes and sizes of conidia were presented in Table 2. The endophytic Trichoderma

TABLE 1. THE GROWTH RATE OF ENDOPHYTIC Trichoderma ON PDA AT ROOM TEMPERATURE

\begin{tabular}{ccccccc}
\hline \multirow{2}{*}{$\begin{array}{c}\text { Trichoderma } \\
\text { isolate }\end{array}$} & \multicolumn{7}{c}{ Average mycelium growth/days (cm) } \\
\cline { 2 - 7 } & $\mathbf{0}$ & $\mathbf{1}$ & $\mathbf{2}$ & $\mathbf{3}$ & $\mathbf{4}$ & $\mathbf{5}$ \\
\hline ET501 & 0 & 1.0 & 4 & 7 & FC & FC \\
ET523 & 0 & 0.9 & 2.9 & 5.1 & 7.3 & FC \\
ET537 & 0 & 0.9 & 3.0 & 5.1 & 7.2 & FC \\
\hline
\end{tabular}

Note: FC - fully colonised in $9 \mathrm{~cm}$ petri dish; PDA - potato dextrose agar.
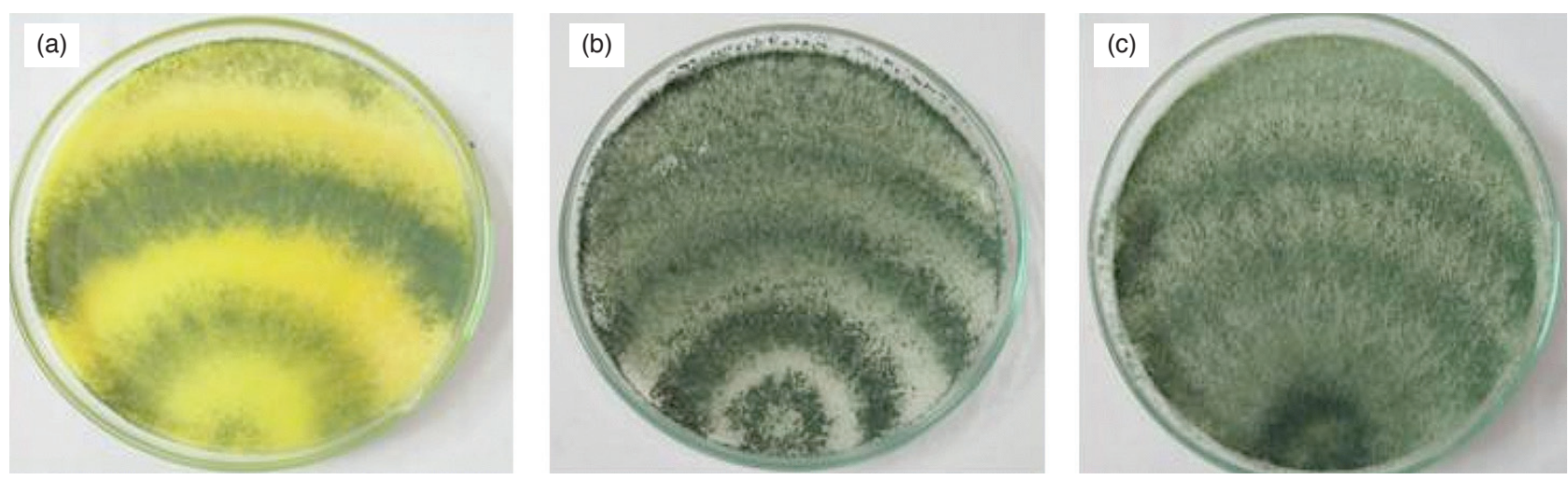

Figure 2. Endophytic Trichoderma isolates. (a) ET501; (b) ET523; (c) ET537. 


\begin{tabular}{|c|c|c|c|}
\hline \multirow{2}{*}{$\begin{array}{l}\text { Trichoderma } \\
\text { Isolate }\end{array}$} & \multirow{2}{*}{ Shape } & \multicolumn{2}{|c|}{ Conidial size } \\
\hline & & Length $(\mu \mathrm{m})$ & Width $(\mu \mathrm{m})$ \\
\hline ET501 & Ellipsoidal & 3.95 & 2.65 \\
\hline ET523 & Globose & 3.30 & 3.30 \\
\hline ET537 & Globose & 3.10 & 3.10 \\
\hline
\end{tabular}

ET501 has an ellipsoidal shape of conidia. On the other hand, both of endophytic Trichoderma ET523 and ET537 isolates showed globose conidia shape (Figures 3). These results are in accordance with Sekhar et al. (2017) who reported the variation of Trichoderma conidia shape including ellipsoidal, subcylindrical, obovoid, globose, and narrow ellipsoid. The endophytic Trichoderma ET501 has conidia with the average diameters of $3.95 \mu \mathrm{m}$ in length and 2.65 $\mu \mathrm{m}$ in width (Figure 3a). Meanwhile, the conidial size of endophytic Trichoderma ET523 and ET537 isolates were almost similar, where endophytic Trichoderma ET523 conidia tended to be slightly bigger than endophytic Trichoderma ET537 conidia (Figures $3 b$ and $3 c$, respectively). Isolate of endophytic Trichoderma ET523 has average size conidia of 3.3 $\mu \mathrm{m}$, while that of endophytic Trichoderma ET537 3.1 $\mu \mathrm{m}$. regions of the rDNA diverged at different rates (Bruns et al., 1991; Latifah et al., 2002). Hence, ITS region becomes the main focus for further molecular identification.

Although the PCR products size among the samples were approximately the same, it may not fully represent the sequence similarity nor phylogenetic relationship. Therefore, the genomic sequence obtained must be further distinguished using analysing tools such as the restriction amplification fragment length polymorphisms (RAFLP), random amplified polymorphic DNA (RAPD), or genomic sequence analysis (e.g. BLAST, phylogenetic tree, etc.). The sequences, thus, obtained were further analysed using BLAST to identify the homologous sequences.

Sequence analyses of endophytic Trichoderma spp. $D N A$. ITS region sequences of each endophytic Trichoderma isolates were further compared to the five possible homologous sequences from NCBI GenBank database. Direct sequencing of ITS region combined with BLAST search has proved to be effective and reliable for the identification of fungi directly from wood in construction (Hogberg and Land, 2004). The five most possible homologous sequences of endophytic Trichoderma spp. from NCBI GenBank database are shown in Table 3. In Table 3a,
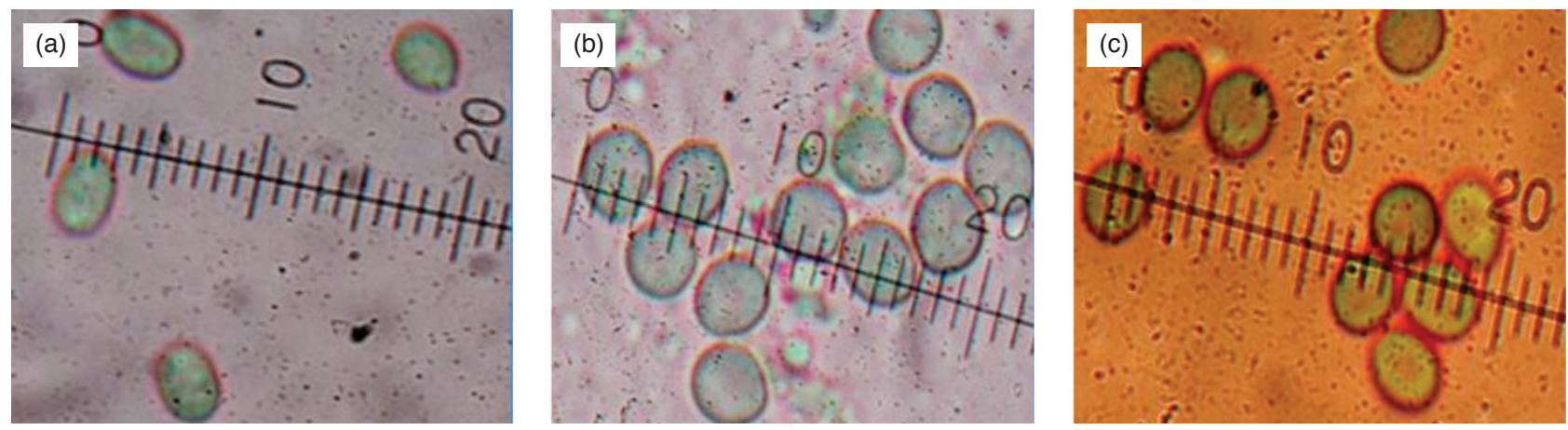

Figure 3. Conidia of endophytic Trichoderma under light microscope with 1000X magnification. (a) ET501; (b) ET523; (c) ET537.

\section{Molecular Identification of Endophytic Trichoderma spp.}

PCR amplification. PCR amplification using ITS1 and ITS4 as primers showed that endophytic Trichoderma isolated from oil palm roots produced PCR product of about $570 \mathrm{bp}$ (Figure 4). The same result was reported by Hermosa et al. (2000) where PCR products of Trichoderma spp. ranged from 560600 bp. Fungal internal transcribed spacer (ITS) region combined the highest resolving power for discriminating closely related species with a high PCR and sequencing success rate across a broad range of fungi (Schoch et al., 2011). Different taxonomic levels could be exploited due to different

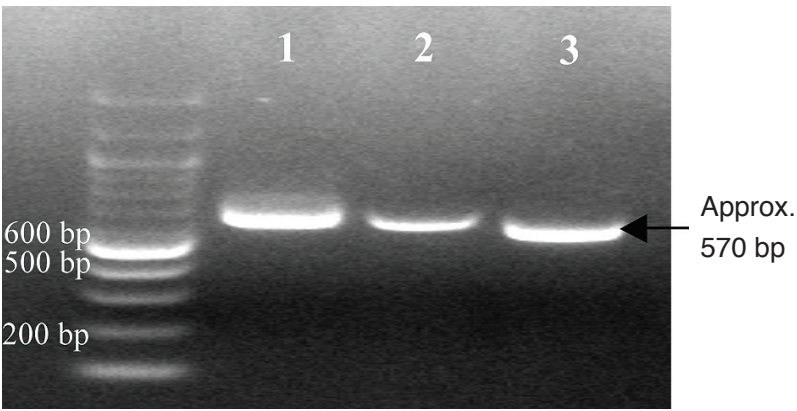

Figure 4. Polymerase chain reaction (PCR) products of the most potential endophytic Trichoderma isolates against G. boninense. $1=E T 501,2=E T 523$, and $3=E T 537$. The target band size is about $570 \mathrm{bp}, \mathrm{M}=100 \mathrm{bp}$ ladder (NEB). 
it was suggested that the endophytic Trichoderma ET501 was identified as $T$. reesei since the most similar homolog to the sequence is $T$. reesei with 99\% of similarity based on BLAST maximum score. Both of endophytic Trichoderma ET523 and ET537 isolates were identified as T. asperellum species as shown in Tables $3 b$ and $3 c$ with $99 \%$ of the maximum identity for all BLAST results. The DNA sequence data gave a detailed and precise information that is highly relevant to endeavours such as evolutionary studies of the origin of organism groups and their geographical distribution, taxonomic classification, and the detection and identification of species in various substrates and habitats (Felsenstein, 2004; Shenoy et al., 2007; Stajich et al., 2009; Nilsson et al., 2011).

The higher similarity rank of homologous sequences from BLAST GenBank database showed the phylogenetic relationship closeness of the isolate. The phylogenetic trees were constructed on the relationships among the homologous microorganisms based on DNA sequence homology (Figure 5). Based on the phylogenetic tree that was constructed using MEGA 5.0 software, endophytic Trichoderma ET501 isolate has the closest relationship with $T$. reesei strain $\mathrm{RHa}$ (Figure $5 a$ ). Meanwhile, endophytic Trichoderma ET523 and Trichoderma ET537 isolates showed the closest relationship with T. asperellum isolate F1 (Figure 5b) and Trichoderma strain Q1 (Figure 5c), respectively. The phylogenetic trees give stronger evidence of the three endophytic Trichoderma isolates (ET501, ET523, and ET537) to be classified as Trichoderma species. Identification of Trichoderma species, traditionally based on morphological aspects, has changed to the use of molecular data, which includes a wide use of ITS regions and ribosomal RNA 5.8S regions amplification (Maymon et al., 2004; Watanabe et al., 2005). The DNA-based method has been used to build the microbial modern taxonomy and widely used in species identification in most fungi (Petti, 2007; Tsui et al., 2011). Identification of the endophytic Trichoderma strains used in the present work, is a key point, which will allow a better future investigation to evaluate bioactivity under different growing conditions and their mode(s) of action. This information, will allow a better microorganism selection, which could be susceptible to a better use

TABLE 3a. THE FIVE MOST HOMOLOGOUS MICROORGANISMS FROM THE NATIONAL CENTRE FOR BIOTECHNOLOGY INFORMATION (NCBI) GENBANK DATABASE IN COMPARISON TO THE ET501 ISOLATE

\begin{tabular}{|c|c|c|c|c|c|}
\hline $\begin{array}{c}\text { Accession } \\
\text { No. }\end{array}$ & Description & $\begin{array}{l}\text { Max. } \\
\text { score }\end{array}$ & $\begin{array}{l}\text { Total } \\
\text { score }\end{array}$ & $\begin{array}{c}\text { Query } \\
\text { value } \\
(\%)\end{array}$ & $\begin{array}{c}\text { Max. } \\
\text { ident } \\
(\%)\end{array}$ \\
\hline KM246746.1 & $\begin{array}{l}\text { Trichoderma reesei strain RHa } 18 \mathrm{~S} \text { ribosomal RNA } \\
\text { gene, partial sequence; internal transcribed } \\
\text { spacer } 1,5.8 \mathrm{~S} \text { ribosomal RNA gene, and internal } \\
\text { transcribed spacer } 2 \text {, complete sequence; and } 28 \mathrm{~S} \\
\text { ribosomal RNA gene, partial sequence }\end{array}$ & 1134 & 1134 & 99 & 99 \\
\hline KT876619.1 & $\begin{array}{l}\text { Trichoderma reesei strain IPBCC93_260 } 18 S \\
\text { ribosomal RNA gene, partial sequence; internal } \\
\text { transcribed spacer } 1,5.8 S \text { ribosomal RNA gene, } \\
\text { and internal transcribed spacer } 2 \text {, complete } \\
\text { sequence; and } 28 S \text { ribosomal RNA gene, partial } \\
\text { sequence }\end{array}$ & 1131 & 1131 & 100 & 99 \\
\hline КТ336514.1 & $\begin{array}{l}\text { Trichoderma reesei isolate M10 } 18 \mathrm{~S} \text { ribosomal } \\
\text { RNA gene, partial sequence; internal transcribed } \\
\text { spacer } 1,5.8 \mathrm{~S} \text { ribosomal RNA gene, and internal } \\
\text { transcribed spacer 2, complete sequence; and } 28 \mathrm{~S} \\
\text { ribosomal RNA gene, partial sequence }\end{array}$ & 1129 & 1129 & 99 & 99 \\
\hline KU729028.1 & $\begin{array}{l}\text { Trichoderma reesei strain ATCC } 26921 \text { small } \\
\text { subunit ribosomal RNA gene, partial sequence; } \\
\text { internal transcribed spacer } 1,5.8 S \text { ribosomal RNA } \\
\text { gene, and internal transcribed spacer 2, complete } \\
\text { sequence; and large subunit ribosomal RNA } \\
\text { gene, partial sequence }\end{array}$ & 1120 & 1120 & 98 & 99 \\
\hline KP263684.1 & $\begin{array}{l}\text { Trichoderma reesei isolate TV219 internal } \\
\text { transcribed spacer 1, partial sequence; } 5.8 S \\
\text { ribosomal RNA gene and internal transcribed } \\
\text { spacer 2, complete sequence; and } 28 \mathrm{~S} \text { ribosomal } \\
\text { RNA gene, partial sequence }\end{array}$ & 1118 & 1118 & 97 & 99 \\
\hline
\end{tabular}


TABLE 3b. THE FIVE MOST HOMOLOGOUS MICROORGANISMS FROM THE NATIONAL CENTRE FOR BIOTECHNOLOGY INFORMATION (NCBI) GENBANK DATABASE IN COMPARISON TO THE ET523 ISOLATE

\begin{tabular}{|c|c|c|c|c|c|}
\hline $\begin{array}{c}\text { Accession } \\
\text { No. }\end{array}$ & Description & $\begin{array}{l}\text { Max. } \\
\text { score }\end{array}$ & $\begin{array}{l}\text { Total } \\
\text { score }\end{array}$ & $\begin{array}{c}\text { Query } \\
\text { value } \\
(\%)\end{array}$ & $\begin{array}{c}\text { Max. } \\
\text { ident } \\
(\%)\end{array}$ \\
\hline KU987251.1 & $\begin{array}{l}\text { Trichoderma asperellum isolate SDLA28 internal } \\
\text { transcribed spacer 1, partial sequence; } 5.8 S \\
\text { ribosomal RNA gene and internal transcribed } \\
\text { spacer 2, complete sequence; and large subunit } \\
\text { ribosomal RNA gene, partial sequence }\end{array}$ & 1024 & 1024 & 98 & 99 \\
\hline KP281701.1 & $\begin{array}{l}\text { Trichoderma asperellum isolate F1 internal } \\
\text { transcribed spacer 1, partial sequence; } 5.8 \mathrm{~S} \\
\text { ribosomal RNA gene and internal transcribed } \\
\text { spacer 2, complete sequence; and } 28 \mathrm{~S} \text { ribosomal } \\
\text { RNA gene, partial sequence }\end{array}$ & 1022 & 1022 & 98 & 99 \\
\hline KU987250.1 & $\begin{array}{l}\text { Trichoderma asperellum isolate SDLA27 internal } \\
\text { transcribed spacer 1, partial sequence; } 5.8 S \\
\text { ribosomal RNA gene and internal transcribed } \\
\text { spacer 2, complete sequence; and large subunit } \\
\text { ribosomal RNA gene, partial sequence }\end{array}$ & 1020 & 1020 & 97 & 99 \\
\hline KT876619.1 & $\begin{array}{l}\text { Trichoderma asperellum isolate CRT2-1 internal } \\
\text { transcribed spacer 1, partial sequence; } 5.8 S \\
\text { ribosomal RNA gene, complete sequence; and } \\
\text { internal transcribed spacer } 2 \text {, partial sequence }\end{array}$ & 1018 & 1018 & 97 & 99 \\
\hline KP281704.1 & $\begin{array}{l}\text { Trichoderma asperellum isolate } \mathrm{F} 4 \text { internal } \\
\text { transcribed spacer 1, partial sequence; } 5.8 \mathrm{~S} \\
\text { ribosomal RNA gene and internal transcribed } \\
\text { spacer 2, complete sequence; and } 28 \mathrm{~S} \text { ribosomal } \\
\text { RNA gene, partial sequence }\end{array}$ & 1016 & 1016 & 97 & 99 \\
\hline
\end{tabular}

TABLE 3c. THE FIVE MOST HOMOLOGOUS MICROORGANISMS FROM THE NATIONAL CENTRE FOR BIOLOGY INFORMATION (NCBI) GENBANK DATABASE IN COMPARISON TO THE ET537 ISOLATE

\begin{tabular}{|c|c|c|c|c|c|}
\hline $\begin{array}{c}\text { Accession } \\
\text { No. }\end{array}$ & Description & $\begin{array}{l}\text { Max. } \\
\text { score }\end{array}$ & $\begin{array}{c}\text { Total } \\
\text { score }\end{array}$ & $\begin{array}{c}\text { Query } \\
\text { value } \\
(\%)\end{array}$ & $\begin{array}{c}\text { Max. } \\
\text { ident } \\
(\%)\end{array}$ \\
\hline KM268676.1 & $\begin{array}{l}\text { Trichoderma asperellum strain DWG3(1) } 18 \mathrm{~S} \\
\text { ribosomal RNA gene, partial sequence; internal } \\
\text { transcribed spacer } 1,5.8 \mathrm{~S} \text { ribosomal RNA gene, } \\
\text { and internal transcribed spacer 2, complete } \\
\text { sequence; and } 28 \mathrm{~S} \text { ribosomal RNA gene, partial } \\
\text { sequence }\end{array}$ & 1029 & 1029 & 97 & 99 \\
\hline KC576729.1 & $\begin{array}{l}\text { Trichoderma asperellum strain CEN768 internal } \\
\text { transcribed spacer 1, partial sequence; } 5.8 \mathrm{~S} \\
\text { ribosomal RNA gene, complete sequence; and } \\
\text { internal transcribed spacer 2, partial sequence }\end{array}$ & 107 & 1027 & 97 & 99 \\
\hline HQ293149.1 & $\begin{array}{l}\text { Trichoderma asperellum strain Q1 } 18 \mathrm{~S} \text { ribosomal } \\
\text { RNA gene, partial sequence; internal transcribed } \\
\text { spacer } 1,5.8 \mathrm{~S} \text { ribosomal RNA gene, and internal } \\
\text { transcribed spacer 2, complete sequence; and } 28 \mathrm{~S} \\
\text { ribosomal RNA gene, partial sequence }\end{array}$ & 1026 & 1026 & 97 & 99 \\
\hline KP263700.1 & $\begin{array}{l}\text { Trichoderma asperellum isolate TV239 internal } \\
\text { transcribed spacer 1, partial sequence; } 5.8 \mathrm{~S} \\
\text { ribosomal RNA gene and internal transcribed } \\
\text { spacer 2, complete sequence; and } 28 \mathrm{~S} \text { ribosomal } \\
\text { RNA gene, partial sequence }\end{array}$ & 1024 & 1024 & 97 & 99 \\
\hline KC403957.1 & $\begin{array}{l}\text { Trichoderma asperellum strain TA2 } 18 \mathrm{~S} \text { ribosomal } \\
\text { RNA gene, partial sequence; internal transcribed } \\
\text { spacer } 1,5.8 \mathrm{~S} \text { ribosomal RNA gene, and internal } \\
\text { transcribed spacer } 2 \text {, complete sequence; and } 28 \mathrm{~S} \\
\text { ribosomal RNA gene, partial sequence }\end{array}$ & 1022 & 1022 & 97 & 99 \\
\hline
\end{tabular}


(a)

KP263684.1 Trichoderma reesei isolate TV219

KU729028.1 Trichoderma reesei strain ATCC 26921

KC847186.1 Trichoderma reesei strain IPBCC93 260

KT336514.1 Trichoderma reesei isolate M10

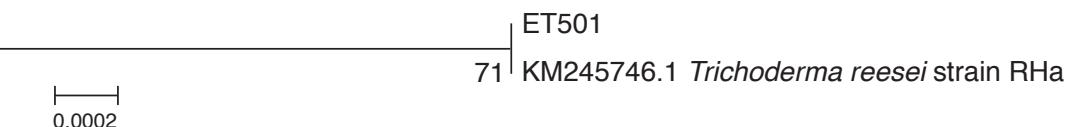

(b)

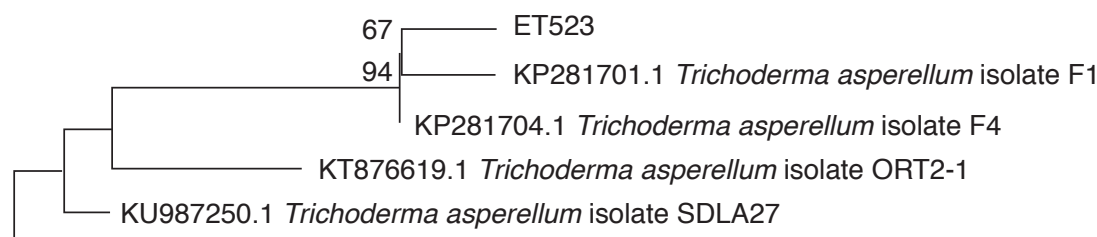

KU987251.1 Trichoderma asperellum isolate SDLA28

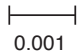

(c)

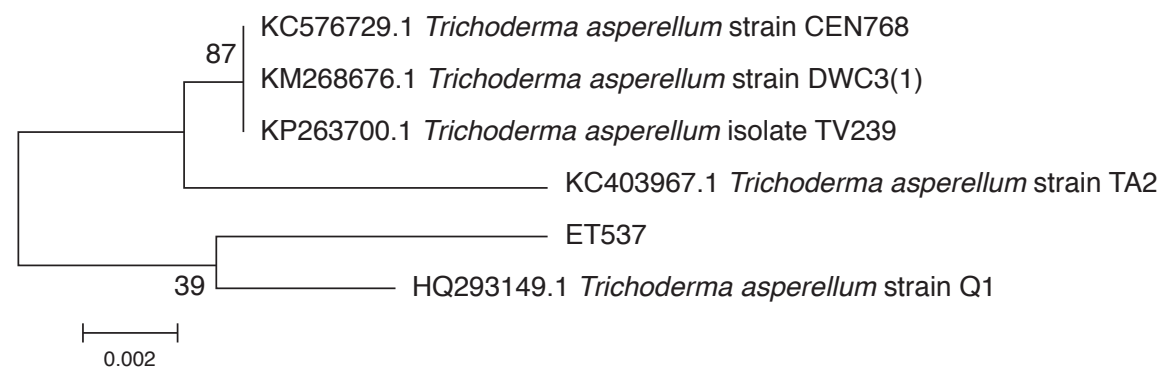

Figure 5. Phylogenetic tree of endophytic Trichoderma spp. isolates with other five homologous microorganisms. (a) ET501 isolate [with National Centre Biology Information (NCBI) query ID: lcl|141685]; (b) ET523 isolate [with National Centre for Biology Information (NCBI) query ID: lcl |61097]; (c) ET537 isolate [with National Centre Biology Information (NCBI) query ID: lcl | 72211].

for plant pathogen control (Guigón-López et al., 2010).

\section{Dual Culture Assay of Potential Endophytic Trichoderma}

The biocontrol activity of endophytic Trichoderma spp. was tested against G. boninense in dual culture assay. All the endophytic Trichoderma isolates were aggressive mycoparasites with highly antagonistic activity against G. boninense. Isolate of endophytic T. reesei ET501 showed to be the most aggressive isolate compared to other isolates according to the pathogen inhibition ability with $95.1 \%$ inhibition, while endophytic T. asperellum ET523 showed 87.1\% and T. asperellum ET537 showed 88.9\% inhibition. Different mycoparasitic activities of each endophytic Trichoderma samples through the PIRG values are shown in Table 4. All the endophytic Trichoderma isolates showed significant inhibitory effect on G. boninense growth. According to Musa et al. (2017), this effect could be most likely due to the production of antibiotic, secondary metabolite compounds or lytic enzymes which contributed to the direct antagonistic degrading effect on the G. boninense cell wall and mycoparasitic activities.

The contact zones between endophytic Trichoderma and G. boninense in all dual culture plates was curved, with concavity oriented towards the G. boninense mycelium (Figure 6). Isolate of

TABLE 4. ANTAGONISTIC ACTIVITY OF POTENTIAL ENDOPHYTIC Trichoderma AGAINST G. boninense THROUGH DUAL CULTURE AND POISON FOOD AGAR ASSAYS

\begin{tabular}{|c|c|c|c|c|c|}
\hline \multirow[t]{2}{*}{ Treatment } & \multirow{2}{*}{$\begin{array}{c}\text { Percentage inhibition } \\
\text { of radial growth } \\
\text { (PIRG) }\end{array}$} & \multicolumn{4}{|c|}{ Percentage inhibition mycelium growth (PIMG \%) } \\
\hline & & $20 \%$ & $40 \%$ & $60 \%$ & $80 \%$ \\
\hline Control & $0^{\mathrm{a}}$ & $0^{\mathrm{a}}$ & $0^{\mathrm{a}}$ & $0^{\mathrm{a}}$ & $0^{\mathrm{a}}$ \\
\hline T. reesei ET501 & $95.1^{\mathrm{b}}$ & $18.7^{\mathrm{b}}$ & $30.1^{\mathrm{e}}$ & $81.3^{g}$ & $100^{\mathrm{k}}$ \\
\hline T. asperellum ET523 & $87.1^{\mathrm{c}}$ & $2.5^{\mathrm{c}}$ & $3.4^{c}$ & $7.5^{\mathrm{h}}$ & $12.3^{\mathrm{d}}$ \\
\hline T. asperellum ET537 & $88.9^{c}$ & $12.3^{\mathrm{d}}$ & $23.4^{\mathrm{f}}$ & $70.5^{\mathrm{i}}$ & $90.5^{1}$ \\
\hline
\end{tabular}

Note: Means within the same column followed by the superscript of same letters are not significantly different at P $<0.05$ with Duncan $(\mathrm{n}=5)$. 
endophytic T. reseei ET501 mycelium was in contact with the G. boninense mycelium in three days of incubation, while other isolates revealed no mycelia contact with $G$. boninense at the same number of days of incubation (Figure 6a). The endophytic $T$. reseei ET501 growth could fully covered the $G$. boninense mycelium in 10 days of incubation, while other isolates only made contact with $G$. boninense mycelium in 10 days of incubation without covering the G. boninense (Figure 6b).

\section{Antibiosis Properties Poison Food Agar Assay of Potential Endophytic Trichoderma}

The endophytic Trichoderma isolates which have promising potential to inhibit G. boninense growth through in vitro assay were then subjected to the poison food agar assay. All isolates have the potential to inhibit the growth of $G$. boninense in poison food agar assay compared to control (Figure 7). The endophytic $T$. reseei ET501 culture filtrate completely inhibited G. boninense growth $(100 \%$ of PIMG) with $80 \%$ incorporation of the culture filtrate into the media, while T. asperellum ET537 and T. asperellum ET523 gave $90.5 \%$ and $12.3 \%$ of PIMG, respectively (Table 4). Endophytic T. reseei ET501 isolate also gave higher inhibition percentage when observed in all concentration of culture filtrate compared to endophytic T. asperellum ET523 and T. asperellum ET537 isolates. Miettinen-Oinonen (2004) reported that T. reesei is one of cellulolytic bestknown organisms, producing readily and in large quantities a complete set of extracellular cellulolytic enzymes. T. reesei also reportedly produces at least three extracellular $\alpha$-1,3-glucanases (Budiarti et al., 2009), which is the key enzyme in the lysis of cell walls during their mycoparasitic action against phytopathogenic fungi (De La Cruz et al., 1995). Meanwhile, T. asperellum biological activity has commonly been related to chitinolytic enzyme production (Viterbo et al., 2002), $\alpha$-1,3-glucanase and $\alpha$ 1,6-glucanase production (Marcello et al., 2010), cellulases and proteases too (Sanz et al., 2004). El-Komy et al. (2015) also reported that T. asperellum isolates significantly reduced the mycelial growth of plant pathogenic fungus Fusarium oxysporum f. sp. lycopersici (FOL). Endophytes may be a better and effective alternative as biocontrol agents as they are buffered from environmental changes which are very important for rhizosphere competence of a biocontrol agent (Sundram, 2013). Therefore, the potential use of endophytic T. reesei and T. asperellum as biocontrol agents against $G$. boninense may be the answer for enhanced biocontrol strategy to overcome BSR.

\section{Morphological Changes of Ganoderma boninense After Interaction with Pontential Endophytic Trichoderma}

Healthy G. boninense mycelium as control can be seen in Figure 8a. Healthy mycelium of $G$. boninense was cultured on PDA medium without the presence of Trichoderma spp. The mycelium was
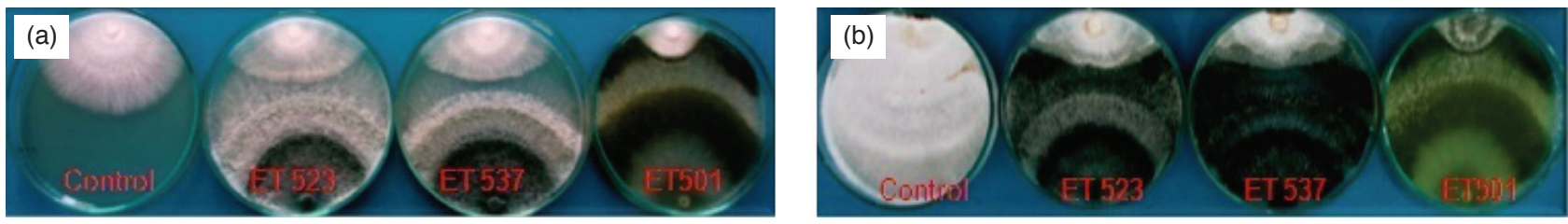

Figure 6. Dual culture assay of endophytic Trichoderma spp. against Ganoderma. (a) Six days of incubation time; (b) Ten days of incubation time.

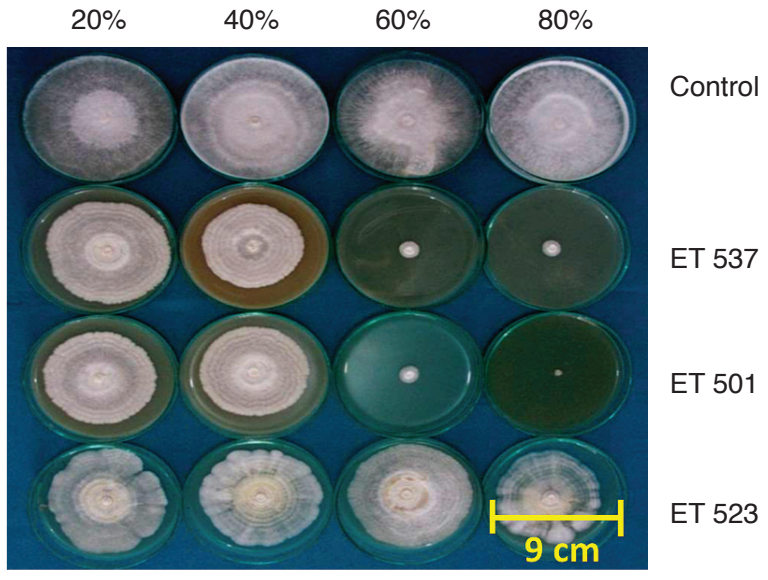

Figure 7. Antibiosis properties via poison food agar assay of endophytic Trichoderma culture filtrate incorporated into growth media at 20\%, $40 \%, 60 \%$ and $80 \%$ concentration. tight and packed with branches of hyphae strands appearing normal with no deformity. The presence of endophytic Trichoderma significantly caused disruption to Ganoderma mycelium. Alexander et al. (2015) also reported that observation under SEM showed that Trichoderma spp. and Bacillus spp. induced stripping of $G$. boninense hyphal structure by destroying the cellular structure. In this research, endophytic T. reseei ET501 and endophytic T. asperellum ET537 gave the most destructive effect to Ganoderma mycelium in six days of incubation. While, endophytic T. asperellum ET523 caused the least destructive effect to $G$. boninense mycelium. Disrupted G. boninense mycelium is characterised by flattened and shrivelled hyphal structure compared to healthy G. boninense hyphae (Figure 8b). 

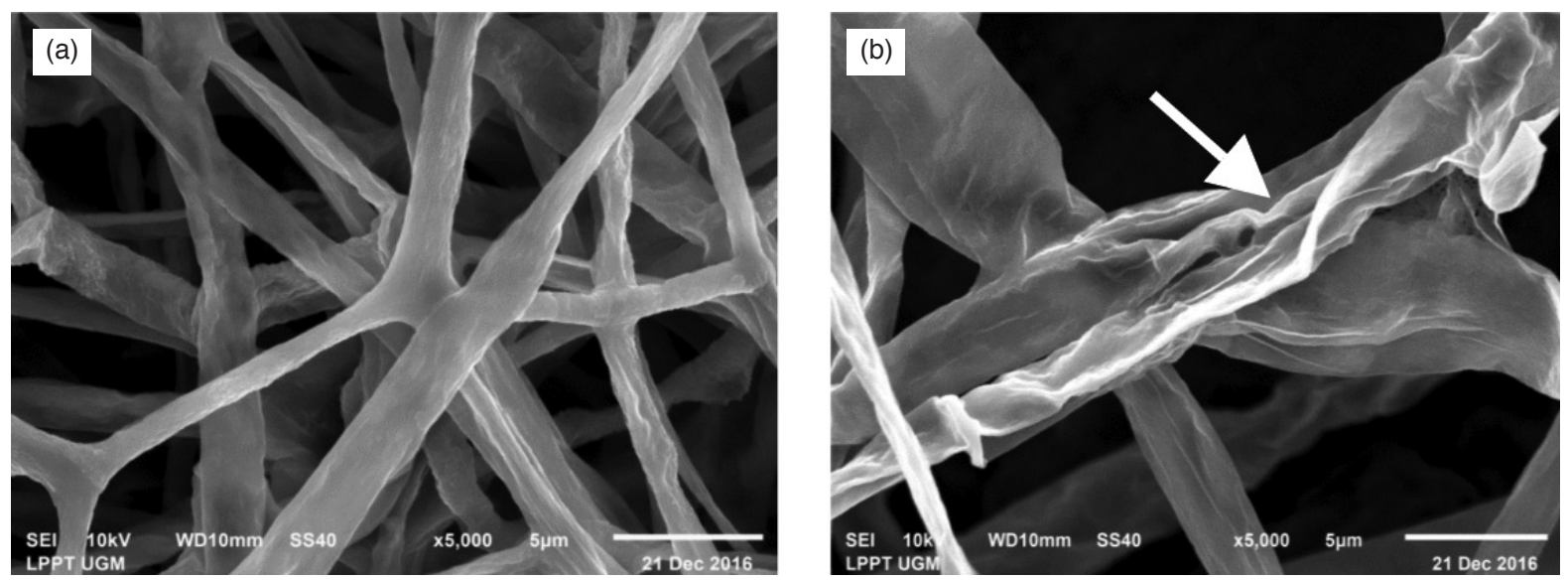

Figure 8. Six-day old G. boninense mycelium observed under scanning electron microscopy (SEM). (a) Healthy G. boninense mycelium at 5000X magnification; (b) G. boninense mycelium destructed by endophytic T. reesei ET501 at 5000X magnification (arrowed).

\section{CONCLUSION}

Three most potential endophytic Trichoderma isolates from oil palm roots were successfully isolated with different characteristics and identified by DNA sequence analysis of 5.8S-ITS region. The endophytic ET501 isolate was identified as Trichoderma reesei strain $\mathrm{RHa}$, while two other isolates namely endophytic ET523 and ET537 were identified as Trichoderma asperellum isolate $\mathrm{F} 1$ and Trichoderma asperellum strain Q1, respectively. All endophytic Trichoderma isolates in this study could give a promising inhibition effect to $G$. boninense. Endophytic T. reesei ET501 was the most aggressive isolate against $G$. boninense compared to endophytic T. asperellum ET523 and T. asperellum ET537 with PIRG inhibitory effect of $95.1 \%, 87.1 \%$ and $88.9 \%$, respectively. Meanwhile, endophytic T. reesei ET501 also showed the strongest antibiosis activity with $100 \%$ inhibition in $80 \%$ concentration, followed by T. asperellum ET537 (90.5\%) and T. asperellum ET537 (12.3\%). Both endophytic T. reesei ET501 and T. asperellum ET537 gave the most destructed effect to $G$. boninense mycelium, while the endophytic $T$. asperellum ET523 caused the least destruction to $G$. boninense mycelium.

\section{ACKNOWLEDGEMENT}

The authors wish to thank the senior management of Asian Agri Group for their support and kind permission to publish this article. The authors also acknowledge their profound gratitude to Asian Agri Research and Development Centre and Royal Golden Eagle (RGE) Technology Centre, Indonesia for providing its facilities to conduct all the research work. Support and service provided by the Universiti Malaysia Sabah (UMS) are also gratefully acknowledged.

\section{REFERENCES}

Alexander, A; Dayou, J and Chong Khim-Phin (2015). Morphological changes of Ganoderma boninense mycelia after challenged by Trichoderma and Bacillus. AIP Conference Proc., 1669: 020075 (2015). https://doi. org/10.1063/1.4919213

Bivi, M R; Farhan, M S N; Khairulmazmi, A and Idris, A (2010). Control of Ganoderma boninense: A causal agent of basal stem rot disease in oil palm with endophyte bacteria in vitro. Int. J. Agric. Biol. Vol. 12: 833-839.

Bruns, T D; White, T J and Taylor, J W (1991). Fungal molecular systematics. Annu. Rev. Ecol. Syst. Vol. 22: 525-564.

Budiarti, S W; Widyastuti, S M and Sebastian, M (2009). Purification and characterization of $\alpha-1,3$ glucanase from the antagonistic fungus Trichoderma reesei. HAYATI J. Biosciences Vol. 16: 115-119.

Cooper, R M; Flood, J and Rees, R W (2011). Ganoderma boninense in oil palm plantations: Current thinking on epidemiology, resistance and pathology. The Planter, 87: 515-526.

De La Cruz, J; Pintor-Toro, J A; Benitez, T and Llobell, A (1995). A novel endo- $\beta-1,3$-glucanase, BGN13.1, involved in the mycoparasitism of Trichoderma harzianum. J. Bacteriol., 177: 6937-6945.

Elad, Y; Chet, I and Henis, Y (1981). A selective medium for improving quantitative isolation of Trichoderma spp. from soil. Phytoparasitica Vol. 9(1): 59-67.

El-Komy, M H; Saleh, A A; Eranthodi, A and Molan, Y Y (2015). Characterization of novel Trichoderma asperellum isolates to select effective biocontrol 
agents against tomato Fusarium wilt. Plant Pathol. J. Vol. 31(1): 50-60.

Felsenstein, J (2004). Inferring phylogenies. Systemic Biology Vol. 53(4): 669-670.

Gams, W and Bissett, J (1998). Morphology and Identification of Trichoderma. Trichoderma and Gliocladium: Basic Biology, Taxonomy and Genetics (Kubicek, C P and Harman, G E eds.). Taylor \& Francis Ltd. p. 3-31.

Guigón-López, C; Guerrero-Prieto, V; VargasAlbores, F; Carvajal-Millan, E; Ávila-Quezada G, D; Bravo-Luna, L; Ruocco, M; Lanzuise, S; Woo, S and Lorito, M (2010). Molecular identification of Trichoderma spp. strains, in vitro growth rate and antagonism against plant pathogen fungi. Revista Mexicana de Fitopatología, 28: 87-96.

Harman, G E (2006). Overview of mechanisms and uses of Trichoderma spp. Phytopathology Vol. 96: 190194. DOI: 10.1094/PHYTO-96-0190.

Harman, G E; Howell, C R; Viterbo, A; Chet, I and Lorito, M (2004). Trichoderma species opportunistic, avirulent plant symbionts. Nature Reviews Microbiology Vol. 2: 43-56. DOI: 10.1038/nrmicro797.

Hermosa, M R; Grondona; Iturriaga, A; DiazMinguez, M; Castro, C; Monte, E and Garcia-Acha (2000). Molecular characterization and identification of biocontrol isolates of Trichoderma spp. Applied and Environmental Microbiology Vol. 66(5): 1890-1898.

Hogberg, N and Land, C J (2004). Identification of Serpula lacrymans and other decay fungi in construction timber by sequencing of ribosomal DNA, a practical approach. Holzforschung Vol. 58: 199-204.

Kredics, L; Hatvani, L; Naeimi, S; Körmöczi, P; Manczinger, L; Vágvölgyi, C and Druzhinina, I (2014). Biodiversity of the genus Hypocrea/ Trichoderma in different habitats. Biotechnolgy and Biology of Trichoderma. p. 3-24.

Larralde, C C; Santiago, M R; Sifuentes, R A; Rodríguez, L I; Rodríguez, P M; Shirai, K and Narváez, Z J (2008). Biocontrol potential and polyphasic characterization of novel native Trichoderma strains against Macrophomina phaseolina isolated from sorghum and common bean. Applied Microbiology and Biotechnology Vol. 80: 167-177.

Latifah, Z; Harikrishna, K; Tan, S G; Abdullah, F and Ho, Y W (2002). Restriction analysis and sequencing of the ITS regions and $5.8 \mathrm{~S}$ gene of rDNA of Ganoderma isolates from infected oil palm and coconut stumps in Malaysia. Annals of Appl. Biol. Vol. 141: 133-142.

Lieckfeldt, E; Samuel, G J; Nirenberg, H I and Petrini, O (1999). A morphological and molecular perspective of Trichoderma viride: Is it one or two species? Applied and Environmental Microbiology Vol. 65: 2418-2428.

Lo, C T; Nelson, E B; Hayes, C K and Harman, G E (1998). Ecological studies of transformed Trichoderma harzianum strain 1295-22 in the rhizosphere and on the phylloplane of creeping bentgrass. Phytopathology Vol. 88: 129-136.

Marcello, C M; Steindorff, A S; Silva, S P; Silva, R N; Mendes, B L A and Ulhoa, C J (2010). Expression analysis of the exo- $\beta-1,3$-glucanase from the mycoparasitic fungus Trichoderma asperellum. Microbiological Research Vol. 165: 75-81.

Maymon, M; Minz, D; Barbul,O; Zveibil, A; Elad, Y and Freeman, S (2004). Identification of Trichoderma biocontrol isolates to clades according to ap-PCR and its sequence analyses. Phytoparasitica Vol. 32: 370-375.

Miettinen-Oinonen, A (2004). Trichoderma reesei Strains for Production of Cellulases for the Textile. Espoo 2004. VTT Publications 550. p. 53-96.

Musa, H; Hassan, M A; Isyaku, M S; Halidu, J and Suleiman, A S (2017). Antagonistic potential of Trichoderma species against Ganoderma disease of oil palm. Nigerian J. Agriculture, Food and Environment, 13(2): 60-67.

Nilsson, R H; Ryberg, M; Sjökvist, E and Abarenkov, $K$ (2011). Rethinking taxon sampling in the light of environmental sequencing. Cladistics Vol. 27: 197203.

Petti, C A (2007). Detection and identification of microorganisms by gene amplification and sequencing. Clinical Infectious Diseases Vol. 44(8): 1108-1114.

Rifai, M A(1969). A revision of the genus Trichoderma. Mycological Papers, 116: 1-56.

Samuels, G I (2004). Trichoderma Morphology. http: / / www.isth.info/methods / method.php? method_ $\mathrm{id}=5$, accessed on 20 November 2018.

Sanz, L; Montero, M; Grondona, I; Vizcaíno, J A; Llobell, A; Hermosa, E and Monte (2004). Cell wall-degrading isoenzyme profiles of Trichoderma biocontrol strains show correlation with rDNA taxonomic species. Current Genetics, 46: 277-286. 
Schoch, C L; Seifert, K A; Huhndorf, S; Robert, V; Spouge, J L; Levesque, C A and Chen, W (2011). Nuclear ribosomal internal transcribed spacer (ITS) region as a universal DNA barcode marker for fungi. PNAS. Vol. 109(16): 6241-6246.

Schubert, M; Fink, F and Schwarze, F (2008). Evaluation of Trichoderma spp. as a biocontrol agent against wood decay fungi in urban trees. Biological Control Vol. 45(1): 111-123.

Sekhar, Y C; Ahammed, S K; Prasad, T N V K V and Devi, R S J (2017). Identification of Trichoderma species based on morphological characters isolated from rhizosphere of groundnut (Arachis hypogaea). International J. Science, Environment and Technology Vol. 6: 2056-2063.

Shah, S; Nasreen, S and Sheikh, P A (2012). Cultural and morphological characterization of Trichoderma spp. associated with green mold disease of Pleurotus spp. in Kashmir. Research J. Microbiology Vol. 7 (2): 139-144.

Shenoy, B D; Jeewon, R and Hyde, K D (2007). Impact of DNA sequence-data on the taxonomy of anamorphic fungi. Fungal Divers. Vol. 26: 1-54.

Stajich, J E; Berbee, M L; Blackwell, M; Hibbett, D S; James, T Y; Spatafora, J W and Taylor, J W (2009). The fungi. Curr. Biol. Vol. 19: 840-845.
Sundram, S (2013). First report: Isolation of endophytic Trichoderma from oil palm (Elaeis guineensis Jacq.) and their in vitro antagonistic assessment on Ganoderma boninense. J. Oil Palm Res. Vol. 25(3): 368-372.

Tsui, C K M; Woodhall, J; Chen, W; Lévesque, C A; Lau, A; Schoen, C D; Baschien, C; Najafzadeh, M J and Hoog, G S (2011). Molecular techniques for pathogen identification and fungus detection in the environment. IMA Fungus Vol. 2(2): 177-189.

Turner, P D (1981). Oil Palm Diseases and Disorders. Oxford University Press, United Kingdom p. 88.

Vinale, F; Sivasithamparan, K; Ghisalberti, E L; Marra, R; Woo, S L and Lorito, M (2007). Trichoderma-plant pathogen interactions. Soil Biology E Biochemistry Vol. 40: 1-10.

Viterbo, A; Montero, M; Ramot, O; Friesem, D; Monte, E; Llobell, A and Chet, I (2002). Expression regulation of the endochitinase Chit36 from Trichoderma asperellum (T. harzianum T-203). Current Genetics, 42: 114-122.

Watanabe, S; Kumakura, K; Kato, H; Iyozumi, H; Togawa, M and Nagayama, K (2005). Identification of Trichoderma SKT-1, a biological control agent against seedborne pathogens of rice. J. General Plant Pathology Vol. 71: 351-356. 